\title{
Cracking Cashew Nut Myths? The Challenges of Gendered Policy Research in the Cashew Sector in Mozambique
}

\section{Nazneen Kanji and Carin Vijfhuizen}

\section{Introduction}

This article is a reflection on collaborative policy research on liberalisation, gender and livelihoods in the cashew sector in Mozambique. ${ }^{1}$ The research aims to examine the effects of liberalisation in the cashew sector from a gender perspective and to study the extent to which women and men's livelihoods may be enhanced by recent strategies to revive the sector. The article has two objectives: first, to illustrate the way in which representations of women's involvement in the cashew sector in earlier research can be contested (cracking some myths) and second, to illustrate some of the challenges involved in translating findings into policy messages, so as to not merely generate another set of myths.

The article begins by providing a brief overview of cashew nut production, processing and trade and sets out the objectives and methods of the research. It then goes on to discuss findings related to women's access to land and cashew trees and the gender division of labour and benefits in cashew processing units. These findings challenged prevalent representations of women but posed difficulties in our attempts to translate them into policy messages. It concludes that some of these challenges arise from the pressures from funders and government to provide policy messages and practical recommendations relating to gender equality in an overall framework which emphasises poverty reduction within an essentially market-oriented neo-liberal approach to development.

\section{Liberalisation and livelihoods in Mozambique's cashew sector}

Smallholder farmers are responsible for about 95 per cent of the marketed production of raw cashew nuts in Mozambique and in total about one million rural households (40 per cent of the rural population) have access to cashew trees (Wandschneider and Garrido-Mirapeix 1999). Raw cashew nuts have been exported from Mozambique since the beginning of the twentieth century, and when the Second World War closed shipping to India, a local processing industry was born. After the war, numerous factories were built for processing the nuts for exports, with women providing the majority of the labour. As Penvenne (1997) has shown, cashew processing was an important source of employment for women, a high proportion of whom were heads of households. Production peaked in 1972 when 216,000 tons were marketed and Mozambique was the world's leading exporter of shelled cashew (kernels).

Since then, drought, war and displacement, inconsistent policies towards the smallholder sector, as well as ageing and diseased trees have affected production. In the mid-1990s, the World Bank pressured the government to liberalise the cashew sector, as a means to revive production, and made it a condition for further loans. Price and trade liberalisation (and the lifting of protectionist measures for industry), became one of the most contentious policy reform issues in Mozambique (Wandschneider and Garrido-Mirapeix 1999; Cramer 1999; Hanlon 2000). By 1997, most factories 
had closed and about 10,000 jobs were lost. Intense national debate led to a raising of tariffs (to 18 per cent) on raw nuts in 1999, although prices are no longer controlled today. The government has put in place a strategy to revive the sector, with the participation of the private sector, non-governmental organisations (NGOs) and communities (INCAJU $1998 ; 2001)$. It is now more widely recognised by international development agencies that promoting trade liberalisation is unlikely to increase benefits to small producers without a range of supporting policies ensuring marketing infrastructure, availability of goods and fair prices, appropriate technology for growing and storing the nuts, and extension services (Deloitte and Touche ILA (Africa) 1997; Mole 2000; Kanji and Barrientos 2002).

Over the last few years, marketed production has risen slowly to about 63,000 tons in 2002-03 from about 40,000 tons in 1997 (IMF 2003). However, processing units only purchased 6,000 tons of raw nuts in 2002 compared with 25,000 tons in 1995-6. Processing initiatives provide only about 2,000 jobs, compared with 10,000 before liberalisation, although this does not include many small, unregistered processing initiatives for domestic and regional markets. Despite the reintroduction of export tax on raw nuts, the revival of in-country processing has been slow and fraught with difficulties. India is the main buyer of Mozambican raw nuts and the international market is intensely competitive. As more countries, such as Vietnam, enter the kernel market, prices of both raw nuts and kernels have fallen on the international market.

Nevertheless, cashew continues to be an important source of cash income for farmers and a nutritious food source (the fruit as well as the nuts). The cashew fruit is home-processed for juice and alcohol and is also sold in local markets, exchanged for labour and used in festivals which strengthen social relations at the community level. Women have a central role in this use of cashew at household and local levels. The jobs which cashew processing units provide are highly sought after, in a context where sources of employment, particularly rural employment, are few and far between. Although cashew may not be as important a crop as it used to be, it is still the country's third most important export. ${ }^{2}$

In seeking to understand the linkages between liberalisation, gender and livelihoods, the research examined who was doing what to produce raw nuts, the shifts in the composition of workers and in working conditions in the processing sector and the actors involved in marketing and trade. The research was carried out in two provinces, Nampula and Gaza. Nampula in the north produces $70-80$ per cent of Mozambique's cashew nuts and Gaza is one of the two main cashew-producing provinces in the south. Nampula has predominantly matrilineal forms of inheritance and succession and Gaza predominantly patrilineal forms of organisation. We used a case study methodology which included the following methods in the selected sites: structured interviews with randomly selected women producers; questionnaire-based interviews with male and female ex-workers of two closed factories as well as three functioning factories; semi-structured interviews with producers, workers and key informants at different levels (local, provincial and national); focus group discussions; participant observation and individual case histories. A major objective of the study was to identify social and institutional constraints to reviving the sector and to provide recommendations to key actors about how to overcome them.

We found that women were very involved in the production and marketing of cashew. They felt they had considerable control over land and trees, particularly in the predominantly matrilineal north, contrary to some influential previous studies based on large-scale surveys. We also found that women were often excluded from interventions to revive production and that they were losing jobs to men in processing units. In our efforts to demonstrate to policy actors that women were important but were often marginalised in the interventions to revive the sector, we faced a number of dilemmas and challenges: how to highlight women's agency while showing how institutions marginalise women? How to avoid oversimplifying complex and dynamic social realities? How to show the relationship between poverty reduction and gender equality without conflating the two issues? How to make the case for gender equality within competitive, predominantly market-led approaches to the sector? The article explores these challenges in relation to our findings on access to land and trees and the division of labour in households and in the work place. 


\section{Women's access to and control over land and cashew trees}

All land in Mozambique belongs to the state. Citizens are legally permitted to use the land they occupy under customary tenure systems. Communities in large areas of northern Mozambique, including Nampula province, follow a tradition of matrilineal succession and inheritance (Braga 2001; Waterhouse and Vijfhuizen 2001). Land tenure patterns are diverse and rights regarding land and tree tenure are intertwined and can be complementary or contradictory (Pitcher, with Kloeck-Jenson 2001). Previous studies (World Bank 2001; CASCA 2002) have tended to base their findings on interviews with men and have asserted that most land and trees are owned by men, generating a picture of women as lacking control over resources.

The World Bank survey was carried out in three main cashew-growing provinces: Nampula, Gaza and Inhambane. The study generated a wealth of data, on numbers of trees, local processing and commercialisation. However, of the 1400 households in the sample, 77 per cent were considered male headed, and 23 per cent were considered female headed. Household trees were simply allocated to "heads" of household and the average number of trees per household was 61 . The female-headed households included in that study were found to have ten trees fewer, on average, than male-headed households (Ministry of Agriculture/ World Bank 1998: 19). In effect, in 77 per cent of the households, the women (as wives) were not interviewed about their role in the cashew sector, let alone daughters and sisters (and sons and brothers) who may also have had cashew trees. A study carried out in the Namige area, in Nampula province (CASCA 2002: 8) states that most of the trees ( 80 per family) are owned by men ( 60 per cent) while the other 40 per cent are divided among women (10 per cent), the family as a whole ( 15 per cent) and grandparents (15 per cent). Once again, men were interviewed and women's views were not represented.

We carried out our first study of women producers (45) in the same area (Namige) and found that that there are diverse patterns of land tenure and that in Nampula's predominantly matrilineal society, most women inherit pieces of land which they cultivate. These allocation practices give women considerable land tenure security. We also found that women were extremely mobile in their marriage arrangements. Women would usually marry, divorce and marry again. In one marriage a woman could move to her husband's home (virilocal), and in the next marriage, the husband could come to her home (uxorilocal). In between the marriages, while divorced or widowed, she lived in her birthplace with her mother where her land provided a constant and an important base of security. A total of 56 per cent of the women interviewed said that the land they were working at the time belonged to them, which did not preclude having land elsewhere.

The ownership of trees is as complex as the land issue. The answer to the question of who "owns" the trees usually went back to who had planted them, often grandparents, and the present "owners" are the ones who inherited them. Although we did not ask as many questions about control over trees as we did in our later study in the south, we did ask about the gender division of labour in cashew. We found that most women did plant trees, which represents a measure of perceived security. We found that there is no distinct gender division of labour in cashew, apart from pruning, which in most cases, is only done by men. In activities, such as sowing and planting, weeding, clearing and harvesting, both women and men participate, albeit in different proportions. ${ }^{3}$

Fortmann et al. (1997) studied the link between land tenure and tree tenure in a patrilineal setting with virilocal marriage patterns. In that setting, women planted fewer trees in their husbands' homes because of lack of security. In our study in the south of Mozambique (Gaza province), the majority of the women (68 per cent) of the 40 interviewed, stated that the land they worked was theirs and they obtained the land from parents-in-law (43 per cent), husbands ( 25 per cent) and parents (10 per cent). Of the rest (32 per cent), 15 per cent said the land belonged to the respondent and her husband, 12 per cent to the husband, and 5 per cent to other family members. Most of the women had a considerable number of trees and also planted trees, again reflecting a considerable level of security. The number of trees which they said belonged to them was impressive: 28 per cent of the women had more than 100 trees; only 15 per cent had 0-20 and the rest had 20-100 trees. Due to changes in marital status, women live on average in three different places where they can plant trees. The most insecure place, 
that is, where women hesitate to plant trees is the place of the husband's parents.

Previous studies had made generalisations about women's lack of access and control to land and trees. We argued that the designation of men as "heads" fails to recognise the many spaces in households where women participate in and have control over resources and resource use; it ignores the complementarities that may characterise the division of labour in households with couples, and it marginalises the majority of women by only referring to women in so-called "female-headed households" at the expense of other women (Chant 1997; Pitcher 1998; Vijfhuizen 2002). The way in which many surveys define "heads" of households and then proceed to only interview them is highly problematic, particularly for the way in which it tends to neglect women's voices and views.

In both the north and the south, we found that women farmers were less likely than men to have access to information and inputs within the new interventions to raise the production of cashew, although many men also lacked access. Women were less likely to belong to farmer associations, which are male-dominated, or to attend village meetings and training courses. Contracts with associations to carry our chemical treatment of trees were signed by men and the operators of the spraying machines were always men. Extension workers were usually male and in keeping with other studies, we found that they tended to contact and pass on information to men. Larger trader/exporters and their agents tend to be men.

Our conclusion was therefore that despite the fact that women are important actors with considerable involvement in and control over cashew production, interventions to promote production have not recognised this adequately and have tended to exclude women.

\section{Oversimplifying complex and dynamic social realities}

In attempting to get policy-makers and organisations intervening in the cashew sector to recognise women's agency, ${ }^{4}$ it was difficult not to overgeneralise and ignore the range of situations we came across in the field.

Women's rights to land and trees are difficult to unravel analytically, since they depend on women's social relationships with others (particularly eldest brothers in matrilineal settings, but also sisters, mothers and husbands). For example, in Nampula province, although 56 per cent of women said the land they worked "belonged" to them, 4 per cent worked on their mothers' land, 13 per cent said the land belonged jointly to their husbands and themselves and 9 per cent said the land was their husbands'. Matrilineal settings are dynamic and there are many situations which may endanger a woman's land tenure security: when residence upon marriage is virilocal, when land is subdivided and more powerful actors (local leaders, companies) take control of the land. Land markets are developing (although in law land belongs to the state) and 22 per cent of our sample said the land had been paid for. Land conflicts between companies, elite groups and smallholders are increasing, not only in peri-urban areas, but in areas of high agricultural potential too (Pitcher 2002). Growing land markets may change women's access to land, even in this predominantly matrilineal setting, as it may create greater differences in access between farmer households who have more financial resources and those who have less. Our research did not really examine socio-economic differentiation between different groups of producers but other research does point to increasing inequalities (Pitcher 2002). The specific opportunities and constraints which different groups of women and men may face in the cashew sector are therefore unexplored.

There were many cases of cooperation between wives and husbands, and brothers and sisters, in buying land and in the division of labour, as we referred to above. One woman referred to "her" land and cashew trees which her husband had contributed towards buying and another man had left "his" land to the woman when they divorced. However, there were also cases in which women expressed their vulnerability and lack of decisionmaking power where they were living with their husbands' family. In sum, we encountered diversity in social relations which affect women's access to and control over trees which can get oversimplified in dissemination to policy-makers.

Stressing women's agency points to their knowledge and capabilities and the ways in which so many women did manage to control resources. However, it can support another myth that women uniformly have control over land and trees. Too great an emphasis on the structures and processes which subordinate women, and a focus on the 
women who did not manage to gain significant control of resources, can lend credence to a myth found in some previous research, where women producers are uniformly represented as passive and somehow "powerless". In trying to engage policymakers and various actors in the cashew sector on gender issues, it was a struggle to avoid "homogenising" women as a category and to give due weight to the complexities of dynamic and context-specific social and economic relations.

\section{The gender division of labour and benefits in cashew processing units}

Our study included interviews with women and men who used to work in large factories in Angoche, Nampula province, which are now closed and with workers in three functioning factories: Namige and Geba in Nampula province and Macuacua in Gaza province in the south.

\subsection{Ex-factory workers in Angoche}

In Angoche, a small coastal town, cashew processing in three large factories was a major source of employment providing some 3,000 jobs. A total of 100 ex-workers ( 50 women and 50 men) from two factories were interviewed. Both factories were privatised in the first half of the 1990s and were closed by 1999 . With privatisation, social services such as health and childcare for workers were lost or deteriorated, since government-run factories in the past had provided monthly contracts with better wage and non-wage benefits. Ex-workers were also of the opinion that unions became the employers' means of controlling workers, rather than clearly defending their interests.

In one of the factories (Angocaju), for which we had full data, privatisation increased the percentage of men workers. In both factories, men secured more jobs than women did, not only in the shelling section (100 per cent men), but also by entering into all the other areas of work in the factory. Although women remained predominant in the peeling and selection sections, 14 per cent of the workers in these sections were men, doing work that has been stereotypically seen as women's work, requiring patience and dexterity. Women and men sometimes worked on different tasks but women worked longer hours than men in the Angoche factories and yet they received the same wages.

In our sample of 50 women, 38 per cent were widows or divorced women and had families larger than the average five members. Paid work had been critical for them. Some married women also pointed out how factory income was a valuable source of independence from their husbands.

We asked workers about their livelihood sources before, during and after factory employment. Women returned to agriculture ( 76 per cent before factory work and after closure) and an increasing proportion of men engaged in agriculture (36 per cent before factory work and 54 per cent after closure). However, it is increasingly difficult to live on agriculture alone and both women and men engaged in petty trade, although they all complained about low demand in a depressed local economy. More men had varied sources of income, outside of agriculture and trade ( 22 per cent compared with 10 per cent of women).

\subsection{Factory workers in the north: Namige and Geba}

The factory in Namige started to function in April 2002 and represents a new smaller-scale enterprise involving collaboration between government, business and NGOs. It was set up by a private entrepreneur with a five-year low-interest bank loan which was guaranteed by the government cashew institute, INCAJU. The factory was designed with the help of TechnoServe, a US NGO which aims to promote entrepreneurial women and men in poor rural areas. The Dutch NGO, SNV, has assisted the owner to contact a Dutch buyer of cashew kernels who operates from Rotterdam and exports to various parts of the world.

At the time of our study, the factory employed 92 workers (56 men and 36 women; 61 and 39 per cent, respectively). When the factory opened, about 1,000 people turned up to apply for jobs, illustrating the real need for cash income in the area. Men workers in the factory were mainly married, whereas almost half of the women workers (47 per cent) were divorced and/or widowed. Headship was used as a selection criterion, based on the view of the management that "female heads" are most in need of cash and therefore more likely to work hard. As in the Angoche factories, more women workers tended to look after larger families than the men.

Men were found in all the leadership roles in the factory. Peeling and selection is mainly done by women (peeling 32, selection 4), but men had also managed to get work in these sections, six men in 
the peeling section and one man in the selection process. Only men (43) worked in shelling. The owner of the factory said that the door of the shelling section was open to women, but that they preferred to work separately. One fact is clear - the men started to work a few days before the women did and were trained to use the machines. According to one manager, before the factory opened, he called a few women to try and use the machines 'but the women said they could not handle the machine'. However, when we tried to use the machines ourselves, it became obvious that while it is a skill that may require some time to acquire, there are no issues of strength involved. Women are often excluded when it comes to the use of machines, but in this case, it is complicated by the fact that shelling involves contact with an acidic substance (cashew nut shell liquid, CNSL), which burns the workers' hands despite the use of coconut oil providing some protection. In focus groups, we sought the views of women themselves on their exclusion from shelling. Some explained they did not want to burn their hands, adding that it would affect their farming work which they said was not a concern for men, but other women said they wanted jobs in the shelling section because 'it is also work through which money can be earned'.

Both women and men work long hours, but more women worked the longest hours per day. At the time of the study, there were ten women who worked 'more than ten hours' compared with five men, in our sample of 34 workers ( 17 men and 17 women). Wages are not fixed, but are paid on a piece-rate basis. Women tended to earn less than their male counterparts, that is, there were more women than men who reported earning the lowest wages (four women and only one man) and only men $(n=6)$ earning the highest wages.

The factory in Geba was established in 1995 by Joao Ferreiro dos Santos (JFS), a large company which is involved in trade in other commodities. In 2002, there was a total of 642 workers ( 538 men and 104 women; 84-16 per cent, respectively). Men worked in all the sections: shelling (100 per cent), peeling (59 per cent), as well as being involved in selection. Interestingly, about two-thirds of the workers in the peeling section were very young so both women and men seem to have "nimble fingers" in youth. In this factory, there was little difference between the hours worked and wages of women and men.

\subsection{Factory workers in the south: Macuacua}

The factory INVAPE (INVestimentos AgroPEcuaria), in Macuacua in Gaza province began functioning in 1998, with a total of 107 workers (62 women and 45 men) of whom 86 (61 women, $25 \mathrm{men}$ ) worked directly in processing. Interestingly, more women than men initially worked in the shelling section in this factory in the south of the country. However, the number of processing workers was reduced to 40 ( 18 women and 22 men) at the beginning of 2003 and to 19 (9 men and 10 women) in June 2003. A greater number and proportion of women than men lost their jobs (51 women: 84 per cent, compared with 16 men: 64 per cent). The decrease in number of workers and output is primarily linked to the management of the factory and the availability of raw cashew in the area.

A total of 15 men and 15 women were interviewed from a total of 40 workers employed in May 2003. A high proportion of women workers were heads of household (67 per cent) but in this case, in the south, men tended to have larger families, probably due to a number of polygamous households in the sample. Women and men both worked long hours, with their day starting at 4.00 a.m. Working conditions in this factory were particularly poor. Once again, women tended to earn less than men, with more women than men earning the lowest wages (12, compared with 5 men) and men the higher wages (10 men compared with 3 women).

The study of ex-workers showed that women had greater difficulties than men in finding alternative sources of income and that cashew processing was an important source of employment for women. The factory workers' study illustrates clearly that when paid employment is scarce and there is huge competition over jobs, men readily move into areas that were dominated by women, breaking down myths concerning women's "nimble fingers". At the same time, men predominated in jobs requiring skills with machines and in positions of leadership. The social construction of what constitutes "appropriate work" for women and men is clear in cashew processing. In India, women comprise 95 per cent of the entire processing sector, using the very same machines as those used in Mozambique. However, in that context, too, men dominate in leadership positions. 


\section{The conflation of gender equality and poverty reduction issues}

In presenting our conclusions on women's declining share of benefits from employment in cashew processing units, there was pressure from various quarters to link our findings to issues of poverty reduction. We did find that women ex-workers have been particularly affected by the loss of jobs in relation to men, that they now have fewer sources of income and are less mobile than men due to domestic responsibilities. We started by making recommendations based on equal rights and the view that development should expand choices for women and men. Our view is that income and independent economic power for women is important. However, to engage with government staff, donors and some NGOs it was necessary to develop more instrumental arguments for gender equality. We therefore argued that jobs for women are important in reducing income poverty, since women tend to be over-represented in poor groups in Mozambique, and that women have greater domestic responsibilities than men and tend to direct their earnings towards improving household welfare. Our findings showed that women tended to save more money than men and directed their earnings differently to men, but the ways in which men spent their money also contributed to household welfare. While some of our arguments can be seen to be tactical shifts (Razavi 1997; Kabeer 2000), we were in danger of over-generalising and reinforcing myths that women are usually generous and caring while men are selfish.

Explaining women's generally lower wages in factories was also a difficult issue since there were multiple reasons which were difficult to weigh up and compare in this study. In part, this is due to the sections in which women predominate - piece rates in the peeling sections tend to be low, or the converse - rates are low because women predominate; this may also be due to women taking more time off work, which may also relate to heavier domestic responsibilities and/or ill-health of women and children; and finally, it may relate to productivity levels, which was the reason given by some male factory managers. We carried out a small study timing six women and eight men working in the shelling section in the INVAPE factory. It showed that women took longer than men to shell 20 nuts (weighing about $104 \mathrm{~g}$ ). On average, women took
2 minutes 22 seconds, while men took 1 minute 50 seconds. For the $25 \mathrm{~kg}$ of nuts they received to shell per day, this average would result in men having a 7.5 hour-day, while women would take 9.5 hours. Gender inequalities in nutrition and health may give rise to inequalities in the productivity of labour, but we did not examine this issue in the study and it is not seen by employers to be their concern.

Finally, recommending equal wages for women and men when most workers receive less than minimum wages is simply inadequate, nor does it seem an adequate goal to recommend that both women and men have the right to be exposed to CSNL. ${ }^{2}$ If the cashew processing sector is to better contribute to livelihoods, for both women and men, then stronger government regulation of factories, more attention to worker safety and minimum wages will be required. ${ }^{5}$ Productivity is the key criterion for employers in an industry which is increasingly forced to cut costs to be competitive on the international market. Cashew prices on the international market have not risen for three years and the pressures which exist along this buyerdriven supply chain make it more difficult to ensure decent wages and working conditions for cashewprocessing workers, both women and men. One of our recommendations is that more attention should be paid in the government strategy to local and regional markets, particularly South Africa, which represents a huge market and does not itself produce cashew nuts. Such a "market diversification" strategy, rather than too much emphasis on capturing shares of the international market, may provide better and more stable livelihoods and benefit women in particular, since our study shows that they tend to be more involved in local and regional markets.

\section{Conclusions}

This research project received considerable media coverage in Mozambique and we engaged directly with the government's cashew institute, producers, factory owners, traders, NGOs and donors to use the findings of the research at national and provincial levels. Our findings contested some of the "myths" prevalent in both international and national organisations - that women uniformly lack control over land and trees, that the gender division of labour in cashew is rigid, that agricultural extension and local organisation is gender-neutral and that women are better suited to some jobs in cashew 
processing which require "nimble fingers". We argued that although women are central actors with considerable control over cashew production, they have tended to be excluded in interventions to promote production. However, we had to be careful not to create a new myth - that women uniformly have control over land and trees. It was a struggle to convey to this range of actors the complexity of gender relations and the way in which these relations intersect with class; in other words, to avoid "homogenising" women and stereotyping men. In cashew processing, the competition over jobs has meant that men are doing jobs which were previously seen to be "women's work", but equal opportunities are not being provided to women to work in the full range of jobs available. Arguments for equal opportunities are difficult in a policy environment which stresses productivity and competition.

It was difficult to argue for alternative visions and approaches to improve the livelihoods of disadvantaged groups, given the current domination of market-led, neo-liberal approaches to development. This was made more difficult for us as researchers by the relative lack of strong grassroots producer and worker organisations which are able to represent the interests of the majority of women and men in policy processes. Findings and recommendations from such policy research may be very selectively taken up, in such a way that they do not challenge powerful interests, at different levels, which underpin much of the unequal distribution of benefits from the cashew sector.

\section{Notes}

1. The International Institute for Environment and Development (IIED) has developed, with partners, a research project on liberalisation, gender and livelihoods focusing on the cashew sectors in Mozambique and India. The research project in Mozambique (2002-2004) was developed in collaboration with Eduardo Mondlane University and financed by the Dutch and Irish Embassies. The authors would like to thank co-researchers Carla Braga and Luis Artur, students who provided field assistance, the numerous individuals and organisations who made the research possible, the farmers and workers who gave us their time and the Irish and Netherlands Embassies in Maputo for funding the research.

2. Cashew is an extremely variable plant. In Mozambique, trees can produce 20 kilos of nuts one year and nothing the next. This is partly due to the impact of powdery mildew (Oidium anacardium), but rainfall, insect infestation, humidity and temperature all affect yields in a variety of ways. The raw cashew nut is attached to and hangs below a false fruit or cashew apple. The fruit is sweet, juicy, pungent in aroma and high in vitamin C. The most significant difficulty in processing cashew nuts is that the hard outer shell, which contains the edible kernel, contains a caustic oil (cashew nut shell liquid, CNSL) which can burn the skin and produce noxious fumes when heated. For household consumption, nuts are typically roasted in shell over an open flame until the oil burns away in a thick black smoke. Kernels from raw nuts roasted this way remain high in protein. Cashew nuts are kidney shaped and brittle which makes it difficult to remove the shell without breakage. Whole white kernels fetch the best price on the world market.

3. In our study, we found that women were actively involved in the marketing of raw cashew nuts. Our findings

challenge those of some previous studies in Nampula (including CASCA 2002: 19), that most incomegenerating activities including the marketing of cashew nuts is dominated by men. A total of 87 per cent of our sample households in Namige did sell raw nuts (39 out of 45) and 74 per cent of women (in the sub-sample of households which do sell nuts) are directly involved in marketing the nuts. The study also showed that cashew remains an important crop for household consumption and as such contributes to household nutrition and food security. A total of 93 per cent of the women interviewed in Nampula said they processed nuts themselves (at home) for consumption, with only one woman reporting that her husband did this work. Some 64 per cent of the women process the fruit in some way, making juice and alcohol which may be consumed, sold or given as gifts or payment in kind, for example, for help in their fields. Women are therefore highly involved in both processing of fruit and nuts at the household level and in the local marketing of raw nuts. Women tend to decide how much of the harvested cashew nuts and other cashew products should be allocated to consumption. Women are particularly active in the use of cashew at the local level and cashew has an important role in household food security, provides income and strengthens social relations (in today's terms, building social capital).

4. A national reference group was formed at the start of the study, comprising government agencies, NGOs, donors, academics and private sector processor/exporters. The research team held periodic meetings with the group. Findings from the first and second years of the study were discussed in national level workshops with a wide group of stakeholders, and in May 2004 final workshops were held in both provinces where the research took place, in which organisations working in the case study districts also participated. 
5. There is currently no minimum wage set for workers in rural industries. The current labour law (9/98), sets a minimum wage for trabalhadores assalariados (waged workers) but it is unclear whether and how the law applies

\section{References}

Braga, C., 2001, 'They're Squeezing Us: Matrilineal Kinship, Power and Agricultural Policies: Case Study of Issa Malanga, Niassa Province', in R. Waterhouse and C. Vijfhuizen (eds), Strategic Women, Gainful Men: Gender, Land and Natural Resources in Different Rural Contexts in Mozambique, Mozambique: University of Eduardo Mondlane (UEM)/Action Aid

CASCA, 2002, Programme Proposal: Support to the Cashew Sector in Nampula Province, Mozambique, Mozambique: ADPP, AMODER and Netherlands Development Organisation (SNV)

Chant, S., 1997, Women-headed Households: Diversity and Dynamics in the Developing World, Basingstoke: Macmillan

Cramer, C., 1999, 'Can Africa industrialise by processing primary commodities? The case of the Mozambican cashew nuts', World Development, Vol 27 No 7: 1247-66

Deloitte and Touche ILA (Africa), 1997, 'Cashew marketing liberalization impact study Mozambique', October, Final Report, Maputo

Fortmann, L., Antinori, C. and Nabane, N., 1997, 'Fruits of their labour: gender property rights and tree planting in two Zimbabwean villages', Rural Sociology, Vol 62 No 3: 295-314

Hanlon, J., 2000, 'Power without responsibility: the World Bank and Mozambican cashew nuts', Review of African Political Economy, Vol 27 No 83: 29-46

IMF, 2003, 'Republic of Mozambique: poverty reduction strategy paper progress report', IMF Country report No 03/98, Washington, D.C.: International Monetary Fund (IMF)

INCAJU, 2001, 'Componente comercialização e industrialicação (parte 1, texto)', Maputo, Mocambique: Ministério da Agricultura e Desenvolvimento Rural

INCAJU, 1998, 'Componente produção, Plano director do caju', Maputo, Mocambique: Instituto de fomento do caju, Ministério da Agricultura e Desenvolvimento Rural

Kabeer, N., 2000, 'Editorial: tactics and trade-offs, revisiting the links between gender and poverty', IDS Bulletin, Vol 28 No 3: 1-13 to cashew workers on piece or task rates. One of the recommendations from our study is the setting of a minimum wage for rural industries such as cashew processing units.

Kanji, N. and Barrientos, S., 2002, 'Trade liberalisation, poverty and livelihoods: understanding the linkages', IDS/IIED Working Paper 159, Brighton: Institute of Development Studies (IDS)

Ministry of Agriculture/World Bank, 1998, 'Cashew production and marketing among smallholders in Mozambique: a gender differentiated analysis based on household survey data', Gender/Cashew Pilot Study Discussion Paper 1, Washington, D.C.: World Bank

Mole, P.N., 2000, 'An economic analysis of smallholder cashew development opportunities and linkages to food security in Mozambique's Northern Province of Nampula', unpublished PhD thesis, Michigan State University, USA

Penvenne, J., 1997, 'Seeking the factory for women: Mozambican urbanization in the later colonial era', Journal of Urban History, Vol 23 No 3: 342-79

Pitcher, A.M., 2002, Transforming Mozambique: The Politics of Privatization, 1975-2000, Cambridge: Cambridge University Press

Pitcher, M.A., 1998, 'Disruption without transformation: agrarian relations and livelihoods in Nampula Province, Mozambique 1975-1995', Journal of Southern African Studies, Vol 24 No 1: 115-40

Pitcher, M.A. with Kloeck-Jenson, S., 2001, 'Men, Women, Memory and Rights to Natural Resources in Zambezia Province', in R. Waterhouse and C. Vijfhuizen (eds), Strategic Women, Gainful Men: Gender, Land and Natural Resources in Different Rural Contexts in Mozambique, Mozambique: University of Eduardo Mondlane (UEM)/Action Aid

Razavi, S., 1997, 'Fitting gender into development institutions', World Development, Vol 25 No 7: 1111-25

Vijfhuizen, C., 2002, The People You Live With: Gender Identities and Social Practices, Beliefs and Power in the Livelihoods of Ndau Women and Men in a Village with an Irrigation Scheme in Zimbabwe, Harare, Zimbabwe: Weaver Press

Wandschneider, T.S. and Garrido-Mirapeix, J., 1999, 'Cash cropping in Mozambique: evolution and prospects', Technical Paper 2, Mozambique: Food Security Unit, European Commission 
Waterhouse, R. and Vijfhuizen, C. (eds), 2001, Strategic Women, Gainful Men: Gender, Land and Natural Resources in Different Rural Contexts in Mozambique, Mozambique: University of Eduardo Mondlane (UEM)/Action Aid
World Bank, 2001, Cashew Production and Marketing in the Smallholder Sector in Mozambique, Washington, D.C.: World Bank 